\title{
Positive Chronotropic and Inotropic Effects of Glucagon on the Canine Isolated Atrium
}

\author{
Shigetoshi Chiba \\ Department of Pharmacology, Tohoku University School of \\ Medicine, Sendai
}

\begin{abstract}
Chiвa, S. Positive Chronotropic and Inotropic Effects of Glucagon on the Isolated Canine Atrium. Tohoku J. exp. Med., 1975, 115 (1), 61-65 Effects of glucagon on SA node pacemaker activity and atrial contractility were investigated in isolated canine atrium preparations which were perfused with blood led from a support dog and suspended in a bath. Glucagon at a dose from 0.1 to $10 \mu \mathrm{g}$ was injected into the sinus node artery, which caused a marked positive chronotropic but a less inotropic effect. The positive inotropic response was simulated by atrial acceleration produced by atrial pacing. Glucagon effects were not influenced by treatment with an adrenergic $\beta$-blocking agent, alprenolol or SQ 11725, which blocked effects of norepinephrine. It was concluded that glucagon is more effective on pacemaker activity than on atrial contractile force, and glucagon effects may not be mediated by an adrenergic $\beta$-mechanism. isolated atrium; atrial contraction; sinus node artery; alprenolol; SQ 11725
\end{abstract}

It is well known that glucagon induces a positive chronotropic and an inotropic effect which are not mediated by beta-adrenergic stimulation (Glick et al. 1968; Lucchesi 1968). Recently, Kimura et al. (1974) showed that glucagon is more effective on chronotropism than on inotropism, using the excised SA node and papillary muscle preparations perfused with blood led from a support dog. More recently Iijima et al. (1974) reported that glucagon is more effective on AV conduction than on chronotropism, using the excised SA and AV node preparations. In the present study, it was attempted to investigate effects of glucagon on SA nodal pacemaker activity and atrial contraction, using the isolated, blood-perfused atrium preparation of the dog heart which originally developed by Chiba et al. in 1972.

\section{Methods}

Eight mongrel dogs, weighing 10 to $12 \mathrm{~kg}$, were anesthetized with sodium pentobarbital, $30 \mathrm{mg} / \mathrm{kg}$ i.v. The right atrium was quickly excised and plunged into a Tyrode's solution at about $4^{\circ} \mathrm{C}$. The right atrium was perfused through the sinus node artery with blood led from the heparinized support dog by the aid of a peristaltic pump (Harvard Apparatus, Model 600-1200). The atrium was suspended in the bath filled with blood at a constant temperature of $37^{\circ} \mathrm{C}$. Isometric tension was measured with a force displacement transducer (Grass FTO3B). Atrial rate was measured with a tachometer

Received for publication, November 19, 1974. 
which triggered by the wave of atrial depolarization of atrial electrogram. Bipolar electrodes for atrial pacing were sutured on the free wall of the atrium. Rectangular pulses of 1-msec duration were delivered through the electrodes using an isolation unit (Grass SIU4A) and an electronic stimulator (Nihon Kohden MSE-3). Drugs used were glucagon hydrochloride (Novo), DL-norepinephrine hydrochloride (Sankyo), DL-propranolol hydrochloride (Sumitomo Chemicals) and DL-2,3-cis-1,2,3,4-tetrahydro-5-(2-hydroxy-3-tertbutylamino)propoxy-2,3-napthalendiol (SQ 11725, Squibb). The volume of injected drug solution was 0.01 to $0.03 \mathrm{ml}$ which was administered in a period of 4 sec through a microinjector (Jintan Terumo).

\section{Results}

Comparison of chronotropic and inotropic effects on the isolated atrium of the dog

When glucagon was administered into the sinus node artery, a marked positive chronotropic and a slight positive inotropic effect were dose-dependently induced in the isolated, blood-perfused atrium of the dog. At a dose range of 0.1 to $0.3 \mu \mathrm{g}$ of glucagon, sinus acceleration was significantly induced but an increase in the tension development was not so clear. As shown in Table 1, the threshold dose for producing a positive chronotropic effect was about $0.1 \mu \mathrm{g}$, while that for doing a positive inotropic one was about $0.3 \mu \mathrm{g}$. Fig. 1 shows typical responses to glucagon and norepinephrine on the atrium. The duration of a positive chronotropic effect of glucagon was long-lasting about 20 to $40 \mathrm{~min}$ at a dose of $1 \mu \mathrm{g}$, about 30 to $60 \mathrm{~min}$ at $3 \mu \mathrm{g}$ and 40 to $80 \mathrm{~min}$ at $10 \mu \mathrm{g}$. But that of a positive inotropic one was rather shorter, about 5 to $10 \mathrm{~min}$ at $\mathrm{I} \mu \mathrm{g}, 10$ to $20 \mathrm{~min}$ at $3 \mu \mathrm{g}$ and 20 to 30 $\min$ at $10 \mu \mathrm{g}$. On the other hand, norepinephrine produced a dose-dependent

TABLE 1. Effects of glucagon and norepinephrine on $S A$ nodal pacemaker activity and atrial contractile force when injected into the sinus node artery of the dog heart

\begin{tabular}{|c|c|c|c|}
\hline $\begin{array}{c}\text { Dose } \\
(\mu \mathrm{g})\end{array}$ & $\begin{array}{c}\text { (A) Maximum increase } \\
\text { in sinus rate } \\
(\%)\end{array}$ & $\begin{array}{c}\text { (B) Maximum increase } \\
\text { in developed } \\
\text { tension }(\%)\end{array}$ & $\begin{array}{c}\text { Ratio } \\
(\mathrm{B}) /(\mathrm{A})\end{array}$ \\
\hline \multicolumn{4}{|c|}{ Glucagon* } \\
\hline $\begin{array}{r}0.1 \\
0.3 \\
1.0 \\
3.0 \\
10.0\end{array}$ & $\begin{array}{r}7.1 \pm 1.6 \\
15.2 \pm 2.0 \\
23.8 \pm 2.8 \\
75.8 \pm 19.3 \\
95.3 \pm 22.1\end{array}$ & $\begin{array}{r}4.2 \pm 2.2 \\
9.1 \pm 4.3 \\
20.6 \pm 5.0 \\
36.8 \pm 10.7 \\
58.3 \pm 13.8\end{array}$ & $\begin{array}{l}0.6 \\
0.6 \\
0.9 \\
0.5 \\
0.6\end{array}$ \\
\hline \multicolumn{4}{|c|}{ Norepinephrine $†$} \\
\hline $\begin{array}{l}0.003 \\
0.01 \\
0.03 \\
0.1 \\
0.3 \\
\end{array}$ & $\begin{array}{r}5.0 \pm 1.0 \\
12.2 \pm 2.2 \\
32.6 \pm 4.3 \\
60.8 \pm 3.8 \\
89.2 \pm 9.0 \\
\end{array}$ & $\begin{array}{r}28.0 \pm 9.9 \\
65.0 \pm 25.0 \\
172.2 \pm 66.6 \\
306.0 \pm 115.1 \\
410.0 \pm 105.0\end{array}$ & $\begin{array}{l}5.6 \\
5.5 \\
5.3 \\
5.0 \\
4.5\end{array}$ \\
\hline $\begin{array}{r}\text { * Value } \\
\text { beats } \\
+ \text { Value } \\
\text { beats }\end{array}$ & $\begin{array}{l}\text { nean } \pm \mathrm{S} . \mathrm{E} \text {. of } 6 \text { experim } \\
\text { a } 6 \text { preparations. } \\
\text { mean } \pm \mathrm{S} . \mathrm{E} \text {. of } 5 \text { experim } \\
\text { n } 5 \text { preparations. }\end{array}$ & $\begin{array}{l}\text { and control sinus rate } \\
\text { and control sinus rate }\end{array}$ & $\begin{array}{l}7 \pm 7.6 \\
6 \pm 9.5\end{array}$ \\
\hline
\end{tabular}




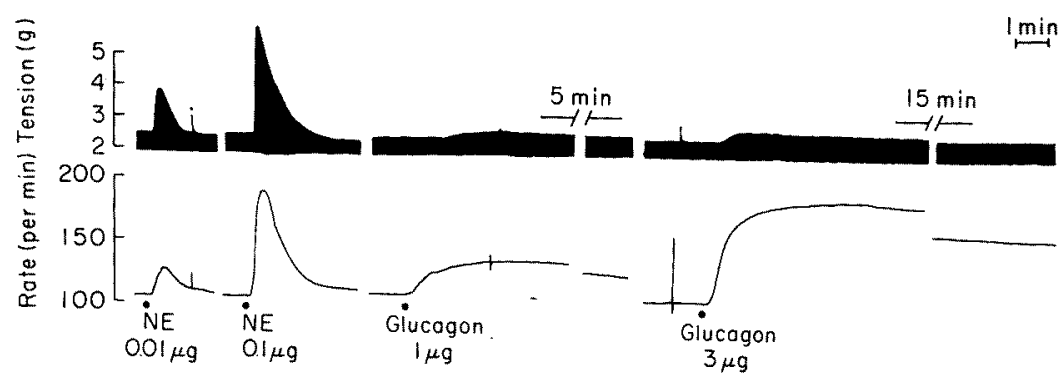

Fig. 1. Effects of norepinephrine (NE) and glucagon on the blood-perfused, isolated atrium of the dog heart. NE and glucagon were injected into the sinus node artery.

increase in contractile force simultaneously with an acceleration of sinus rate. The ratio of doses of glucagon and norepinephrine for inducing $50 \%$ increase in sinus rate is roughly 15:1. The one in the developed tension, however, is roughly $1000: 1$. Summarized data are shown in Table 1.

Effects of alprenolol and $S Q 11725$ on effects of glucagon and norepinephrine

Effects of glucagon were not influenced by alprenolol or SQ 11725. Alprenolol at a dose range of 0.1 to $0.3 \mu \mathrm{g}$ did not cause significantly negative chronotropic and inotropic effects, and SQ 11725 which is one of new beta-adrenergic blocking agents also did not cause significantly negative ones at 0.3 to $1 \mu \mathrm{g}$. Alprenolol or SQ 11725 at doses of 0.1 to $0.1 \mu \mathrm{g}$ markedly suppressed effects of $0.01 \mu \mathrm{g}$ of norepinephrine, but did not suppress that of 0.3 to $1 \mu \mathrm{g}$ of glucagon in three preparations. Fig. 2 shows the effect of SQ 11725 on the actions of norepinephrine and glucagon.

\section{Discussion}

It is generally accepted that glucagon induces positive chronotropic and inotropic effects (Farah and Tuttle 1960; Regan et al. 1964). However, as Kimura et al. (1974) reported, glucagon is more effective on chronotropism than on inotropism, using the excised canine SA node for chronotropism and the papil-

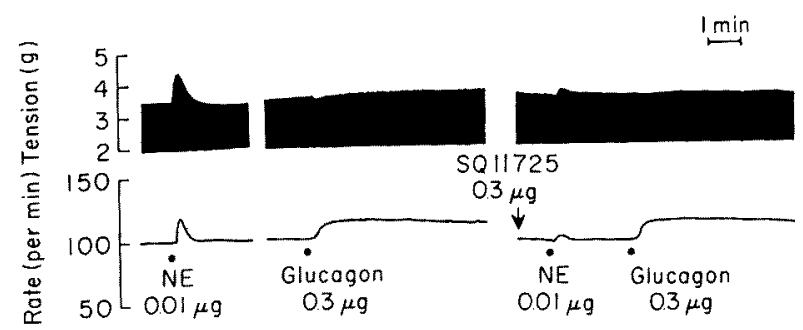

Fig. 2. Effects of a beta-adrenergic blocking agent, $S Q 11725$, on positive inotropic and chronotropic responses to norepinephrine (NE) and glucagon. 


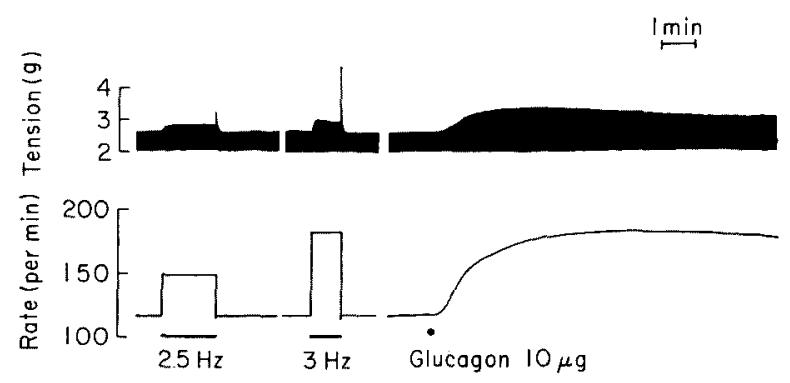

Fig. 3. Comparison of positive inotropic effects of glucagon and electric pacing. The free wall of the atrium was paced at $2.5 \mathrm{~Hz}(150$ beats $/ \mathrm{min})$ and $3 \mathrm{~Hz}$ (180 beats $/ \mathrm{min}$ ) which correspond to the maximum chronotropic response to $10 \mu \mathrm{g}$ of glucagon injected into the sinus node artery of the isolated atrium.

lary muscle preparation for inotropism. Even in the present study, it was demonstrated that in the canine atrium preparation glucagon is more effective on SA node pacemaker activity than on atrial contractile force. But, in this study, as the spontaneous beating preparation was used, an increase in the contractile force induced by glucagon is partially due to increasing sinus rate. Isometric developed tension in the canine atrium had been shown to increase consistently with increasing heart rate over a wide range (Graham et al. 1967). Fig. 3 shows that increases in frequency by electric pacing on the free wall of the atrium cause a slight increase in the contractile tension development. Therefore, an actual increase in the contractile force by glucagon may be less than that shown in Table 1, although, for an equal increase in sinus rate, glucagon causes 10 times less increase in the developed tension than norepinephrine. Thus, a positive inotropic effect by glucagon on the atrial muscle are very similar to that on the papillary muscle in the percent increase in the developed tension.

Previously, Whitehouse and James (1966) reported that glucagon-induced positive chronotropic effect can be reversed or blocked with beta-receptor blockade, but only by the use of relatively high concentrations of blocker, at which level there is some direct negative chronotropic effect by the blocking agent itself. They suggested that the possibility of an associated adrenergic component has not been eliminated. However, if effect of glucagon has an adrenergic component, it is hard to understand the reason why glucagon induces predominantly chronotropic effect with a slight or little positive inotropic effect. Moreover, in the present study, alprenolol or SQ 11725 was used as an adrenergic beta-blocking agent, because either drugs have less depressant action than most beta-blocking agents (Hashimoto et al. 1969, 1970; Evans et al. 1974). By the use of alprenolol or SQ 11725 , effects of norepinephrine were markedly inhibited, although glucagon effects were little influenced. Thus, glucagon-induced positive chronotropic effect may not participate in an adrenergic mechanism.

Catecholamines and glucagon stimulate cardiac adenyl cyclase and it has been suggested that the cardiac effects of these hormones are mediated by cyclic $3^{\prime}, 5^{\prime}$ - 
AMP (Murad et al. 1962; Robison et al. 1967). However, in the present study, it was demonstrated that a positive inotropic response to glucagon was less prominent than a positive chronotropic one. Therefore, it is not entirely obvious whether an increase in intracellular cyclic AMP by activation of adenyl-cyclase plays an essential role on the positive inotropic effect.

\section{Acknowledgments}

I wish to thank the Kodama Limited for the supply of glucagon, and express my sincere thanks to Mr. Shoji Hayashi for his assistance.

\section{References}

1) Chiba, S., Kubota, K. \& Hashimoto, K. (1972) Double peaked positive chronotropic response of the isolated blood-perfused S-A node to caffeine. Tohoku J. exp. Med., $107,101-102$.

2) Evans, D.B., Parham, C.S., Peschka, M.T. \& Laffan, R.J. (1974) On the positive inotropic action of procainamide. Pharmacologist, 16, 246.

3) Farah, A. \& Tuttle, R. (1960) Studies on the pharmacology of glucagon. J. Pharmacol. exp. Ther., 129, 49-55.

4) Glick, G., Parmley, W.W., Wechsler, A.S. \& Sonnenblick, E.H. (1968) Glucagon. Its enhancement of cardiac performance in the cat and dog and persistance of its inotropic action despite $\beta$-receptor blockade with proprmolol. Circulat. Res., 22, 789-799.

5) Graham, T.P., Powell, W.J., Clancy, R.L. \& Gilmore, J.P. (1967) Characterization of the frequency-force relationship in the dog atrium in situ. Circulat. Res., 20, 338-348.

6) Hashimoto, K., Endoh, M., Tamura, K. \& Taira, N. (1970) Comparison of $\beta$-adrenergic blocking activity of DCI, H 56/28, ICI50172, LB46, methoxamine, MJ1999 and propranolol in the blood perfused canine papillary muscle preparation. Experientia (Basel), 26, 757-759.

7) Hashimoto, K., Ohkuda, K., Chiba, S. \& Taira, N. (1969) Beta-adrenergic blocking effects of dichloroisoprenaline (DCI), H 56/28, I.C.I. 50172, LB 46, methoxamine, MJ 1999, and propranolol on the sinus node activity of the dog heart. Experientia (Basel), 25, 1156-1157.

8) Iijima, T., Motomura, S., Taira, N. \& Hashimoto, K. (1974) Comparison of effects of glucagon and isoprenaline on atrio-ventricular conduction and sino-atrial rate in the dog heart. Clin. exp. Pharmacol. Physiol., 1, 241-248.

9) Kimura, T., Kokubun, M. \& Hashimoto, K. (1974) Primary effect of glucagon on positive chronotropism. Jap. J. Pharmacol., 24, 279-283.

10) Lucchesi, B.R. (1968) Cardiac actions of glucagon. Circulat. Res., 22, 777-787.

11) Murad, F., Chi, Y.M., Rall, T.W. \& Sutherland, E.W. (1962) Adenyl cyclase: III. The effects of catecholamines and choline esters on the formation of adenosine $-3^{\prime}, 5^{\prime}$ phosphate by preparations from cardiac muscle and liver. J. biol. Chem., 237, 12341238.

12) Regan, T.J., Lehan, P.H., Henneman, D.H., Behar, A. \& Hellems, H. .K (1964) Myocardial metabolic and contractile response to glucagon and epinephrine. J. Lab. clin. Med., 63, 638-647.

13) Robison, G.A., Butcher, R.W. \& Sutherland, E.W. (1967) Adenyl cyclase as an adrenergic receptor. Ann. N.Y. Acad. Sci., 139, 703-723.

14) Whitehouse, F.W. \& James, T.N. (1966) Chronotropic action of glucagon on the sinus node. Proc. Soc. exp. Biol. Med. (N.Y.), 122, 823-826. 